\title{
Linguistic and speaking nature of French anthroponymy
}

\author{
Kamolova Sanobar Jabborovna ${ }^{1}$ \\ ${ }^{I}$ A senior teacher of the Department of "Foreign Languages", Bukhara Engineering \\ Technological Institute, +998909118995 \\ Email: $\underline{\text { sanobar6399@mail.ru }}$
}

\begin{abstract}
The article deals with the issues of linguistic and verbal coherence of the formation of the name of a person and his owner. If an anthroponym has an independent meaning and, therefore, can be used without qualifiers, it can be associated with all categories of determinants in most of its usual applications.
\end{abstract}

Keywords: anthroponymy, linguistic character, the meaning of anthroponymy, in speech activity, denotation, connotation, discourse.

\section{INTRODUCTION}

The fact that anthroponymy in modern linguistics began to be given separately as a linguistic character prompted us to also study the linguistic and colloquial features of the meaning of the French name and surname. In this article, we will focus on the issues of linguistic and verbal coherence of the formation of a person's name and its owner, as well as on the meaning of anthroponymy, as well as on additional semes that arise during the stage-by-stage application of anthroponymy in language and speech and which can be implemented in accordance with speech conditions.

\section{LITERATURE REVIEW}

Currently, many researchers recognize that anthroponymy is a sign that has full denotation and significance not only at the level of speech, but also at the level of language. For example: according to Yu.S. Stepanova, the person's name has been with him all his life since his birth, he is a replacement, a representative of the person himself, both in a narrow family circle and in wider areas of communication, in official documents (Stepanov 2002: 172-179). Since the function of applying instead of the objects of Genesis would be characteristic of signs, this means that the anthroponym fairly acquires the status of a sign. Recognizing the full virtue of anthroponymy at the language level scientists are trying to solve the question of the exact meaning of anthroponyms, more precisely, which components should be included in its designation and or meaning. Nikitin's opinion on this subject is remarkable. In his opinion, since the anthroponym is a sign, it means that it has a certain meaning [Nikitin 2003: 115-122]. As part of this value, only denotation is distinguished as a mental reflection of the referent, it is noted that the anthroponym has a denotative value [Nikitin 2003: 169-170; Paducheva 2004: 81-82]. Several scholars commented on the linguistic individual meaning of the famous anthroponyms. This implies that every known anthroponym consists of a category represented by one member and corresponding to it [Ball 2001: 88; Damourette, Pichon 1911: 520-522]. Thus, the value is added to the information that this participant provides. Other researchers interpret encyclopedic knowledge about an object as a component of context [Superan. 1986: 104;]. From time to time, the authors interpret the concept of "meaning" as the meaning of "meaning" and include it in the designation and widely interpret it. In this case, any information associated with the name and its owner is entered into the signal [Ermolovich 2005: 67]. Different opinions are also made about the nominal functions of famous anthroponyms. For example, let's compare these two points from the collection of scientific papers "Nomination of Nominees": "Anthroponyms do not always describe" objects (in the broad sense of the word, persons, toponyms are ours), no true or false information about them says nothing, but at the same time, "since the famous name is focused on one subject, its content corresponds to a whole set of properties that cannot be distinguished in this subject" [Serebrennikov, Ufimtseva 2006]. 


\section{DISCUSSION}

In addition to the semantic information provided by the forms of linguistic expression, one can often see that the semantic structure of the French anthroponym is enhanced by the use of certain determinants in speech activity. L'illustre Gobseck, le maître des Patma, des Cisonnet, des Werbrust, des Kellei et des Nucinsen (Balzac). The Great Nucingen, Napoleon de Finance ... (Balzac). Ce Chat Extermina $\neg$ teur, / Vrai Cerbère, était craint une lieue à la ronde. (La Fontaine) La vie secrète d'un Chevreuse les intriguait plus Queen of Poten College, art academy plus queen of jockeys Comédie, Iils Etaient Les Rtwine de notre époque (Giro, Bella). The semantic features of the namespace are inextricably linked in all of these contexts. In this case, a famous horse generates some or all of the keywords of a group of horses. This means that the determinants used with the anthroponym have the same meaning and the same meaning as those used before the anthroponyms. In other contexts, the single form of a particular artifact can also help select or create an image of a particular referent: either shows a typical description ("natural identifier"); or represents a person in one of his affairs; or, through anthomasia, a person conveys to a person amazing features of another. Of course, to enrich the contents of the horse, additional means are used - an adjective in front of the famous horse or a subsequent predecessor or verbal identifier: Le sage Ulysse, / le vaillant Diomède, Ajax l'impétueux (La Fontaine), C'est ainsi que Roland épousa la belle Aude (В. Гюго). Виктор Гюго, royal legitimist. The specific articulation used in the title can add meaning to the name archaic or specific for a particular region, and is most often used for singers: T'en fais pas, la Marie, t'es jolie (chanson) - La Collas. Various semantic procedures are used when the plural form of a particular artifact is used. In such contexts, the characteristic of each of the distinguishing nouns is multiplied to consider a collection of people with the same name or to obtain an image that can be applied from one person to another. This condition leads to metaphorical use: Les Chateaubriand on habit Combourg (Shatobrian family). Les Chateaubriand on chanté la beauté des ruines (authors with the same description as Chateaubriand, including Chateaubriand himself). Les Chateaubriand d'aujourd'hui (modern authors look like Chateaubriand). Some anthroponyms include complete articular forms that are continuous and unchanged at the syntagmatic level, for example: Le Clézio, La Fontaine, Le Corbusier: Les livres de Le Clézio, * Jardin de Le Nôtre / * du Nôtre, Un immeuble de Le Corbusier /* du Corbusier. Various semantic sensitivity can also be introduced into the well-known semantics of a horse using an indefinite expression: J'ai connu un Dupont autrefois (un porteur non autrement déterminé du nom propre). Un poétique des ruines devait être illustré par un Châteaubriand (writer with the same description as he) En haut les Keller, les du Tillet (...); un peu plus bass, Les Palma, Les Cigonnet, Les Gobseck; encore plus bass, le Sabanon, le Chabuasso Puis, enfin, apré le Mont de Pite (...) and Cerese! (Balzac) (Un Cérizet, representing Cérizet himself) // se trouvera toujours un Chateaubriand pour en enchanter ses contemporaries (author of the same, but the same time from different times). Uncertain articulation may interrupt the specific request of a famous horse referent (e.g. time or quality): Je suis entré dans un Paris Desert. - Jai rencontré hier un Gaston très excité par son succès. Particle artifacts have a metonymic meaning for the famous horse semantics: a product or typical behavior of a person with the same name: Hier, j'ai écoulé du Bach - J'aime beaucoup lire du Simenon. $\mathrm{Te}$, c'est bien du Colette - Cette faire de faire, c'est dit Gaston Tout Craché. The determinant of property often adds the meaning of an affective or special pragmatic attitude to a person of communication, mainly to the first person, or sometimes easier to the second person: Mon Pierre - Mon petit Pierre - Mon cher Pierre. Ta Marie - Ta chère Marie. Sa Béatrice - Sa Chère Béatrice. Using the determinant before the anthroponym means something paradoxical and superfluous; thus you can always skip something without having to distort it. It looks like a surplus, and it even encourages its use in consonants: Quel génie que ce Chateaubriand Ax! Ce Raymond, Quel Farceur! C'est Ainsi Que J'ai Perdu Toute une Journée de ma vie à La Corogne, cet Escurial à rebours, ù Picasso, ce Philippe II de la peinture moderne and reçu le sacre de son per qui abdiquait (Cendrars).

\section{CONCLUSION}

Thus, even if the anthroponym has an independent meaning and, therefore, can be used without qualifiers, it can be associated with all categories of determinants in most of its usual applications. In these applications, determinants act as the main grammatical tools that help shape the scale of anthroponym content. 


\section{REFERENCES}

1. Stepanov Yu. S. Concept / Yu. S. Stepanov // Big Encyclopedic Dictionary. Linguistics / Ch. ed. V. N. Yartseva. - M .: Bolshaya Ros. Encycl., 2002 .- 172-179 p.

2. M.V. Nikitin // Foundations of cognitive semantics [Text]: textbook for universities / M.V. Nikitin. - SPb.: 2003: 115-122p.

3. M.V. Nikitin // Foundations of cognitive semantics [Text]: textbook for universities / M.V. Nikitin. - SPb .: 2003169-170 P

4. Ball 2001: 88; Damourette, Pichon 1911: Des mots a la pensee. Essai de grammaire de la lange française. 520-522 p.

5. Superanskaya A.V. Modern Dictionary of Personal Names: Comparison. Origin. Spelling M .: Iris Press, .1986: 104p

6. Ermolovich, D.I. Proper names at the junction of languages and cultures / D.I. Ermolovich. - M.: 2005.67p.

7. Serebrennikov, Ufimtseva Language nomination: general issues. M .: Nauka, 2006

8. Lefigaro. - URL: http://www.lefigaro.fr (date of the application 10.11. 2013) 